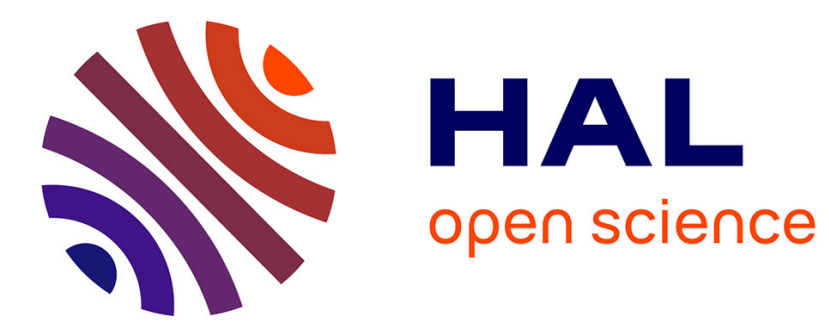

\title{
ECONOMIC GROWTH, INFLATION AND OIL SHOCKS: ARE THE 1970s COMING BACK?
}

\author{
Maria Dolores Gadea, Ana Gómez-Loscos, Antonio Montañes
}

\section{To cite this version:}

Maria Dolores Gadea, Ana Gómez-Loscos, Antonio Montañes. ECONOMIC GROWTH, INFLATION AND OIL SHOCKS: ARE THE 1970s COMING BACK?. Applied Economics, 2011, 44 (35), pp.45854599. 10.1080/00036846.2011.591741 . hal-00720578

\section{HAL Id: hal-00720578 https://hal.science/hal-00720578}

Submitted on 25 Jul 2012

HAL is a multi-disciplinary open access archive for the deposit and dissemination of scientific research documents, whether they are published or not. The documents may come from teaching and research institutions in France or abroad, or from public or private research centers.
L'archive ouverte pluridisciplinaire HAL, est destinée au dépôt et à la diffusion de documents scientifiques de niveau recherche, publiés ou non, émanant des établissements d'enseignement et de recherche français ou étrangers, des laboratoires publics ou privés. 


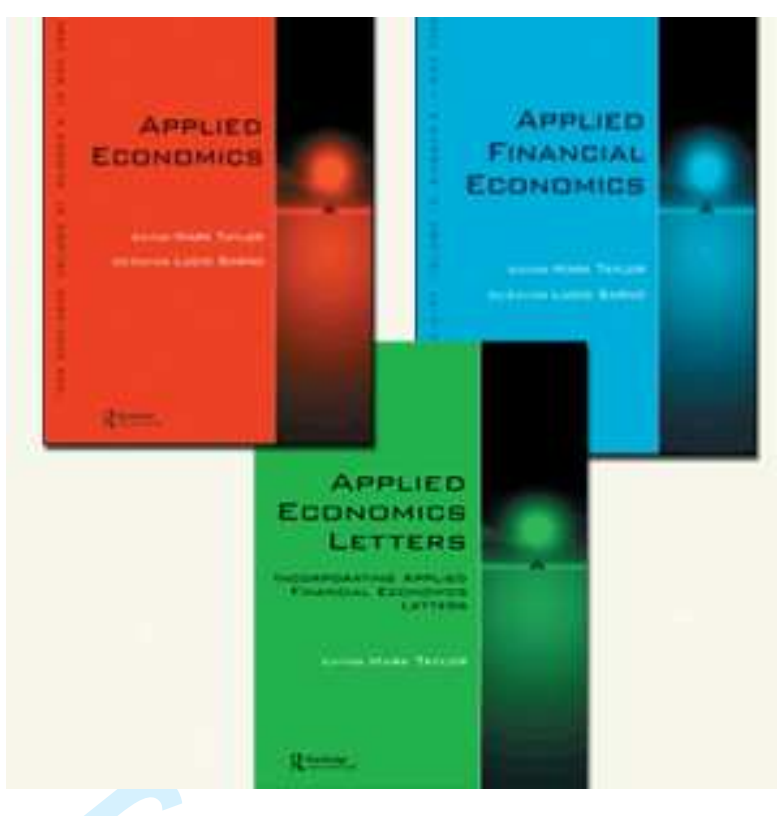

\section{ECONOMIC GROWTH, INFLATION AND OIL SHOCKS: ARE THE 1970s COMING BACK?}

\begin{tabular}{|c|c|}
\hline Journal: & Applied Economics \\
\hline Manuscript ID: & APE-2010-0489.R1 \\
\hline Journal Selection: & Applied Economics \\
\hline $\begin{array}{r}\text { Date Submitted by the } \\
\text { Author: }\end{array}$ & 31-Mar-2011 \\
\hline Complete List of Authors: & $\begin{array}{l}\text { Gadea, Maria Dolores; University of Zaragoza, Applied Economics } \\
\text { Gómez-Loscos, Ana; University of Zaragoza, Applied Economics } \\
\text { Montañes, Antonio; University of Zaragoza, Economic Analysis }\end{array}$ \\
\hline JEL Code: & $\begin{array}{l}\text { C32 - Time-Series Models < C3 - Econometric Methods: } \\
\text { Multiple/Simultaneous Equation Models < C - Mathematical and } \\
\text { Quantitative Methods, E31 - Price Level|Inflation|Deflation < E3 - } \\
\text { Prices, Business Fluctuations, and Cycles }<\text { E - Macroeconomics and } \\
\text { Monetary Economics, E32 - Business Fluctuations |Cycles }<\text { E3 - } \\
\text { Prices, Business Fluctuations, and Cycles }<\text { E - Macroeconomics and } \\
\text { Monetary Economics, Q43 - Energy and the Macroeconomy < Q4 - } \\
\text { Energy < Q - Agricultural and Natural Resource Economics }\end{array}$ \\
\hline Keywords: & oil shocks, inflation, business fluctuations, structural breaks \\
\hline
\end{tabular}




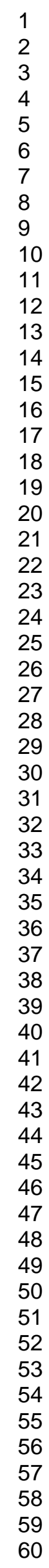

\section{SCHOLARONE ${ }^{m}$ \\ Manuscripts}

7

25

26

27

29

30

31

33

34

35

36

37

38

41

42

43

45

46

47

48

49

51

52

53

54

55

57

58

59

60 


\title{
ECONOMIC GROWTH, INFLATION AND OIL
}

\author{
SHOCKS: ARE THE 1970s COMING BACK?
}

by Ana Gómez-Loscos ${ }^{(1)}$, María Dolores Gadea ${ }^{(2)}$ and Antonio Montañés ${ }^{(2)}$

\author{
Corresponding author: \\ M. Dolores Gadea \\ Department of Applied Economics \\ Facultad de Económicas \\ Gran Vía, 4 \\ 50005 Zaragoza \\ SPAIN \\ e-mail: lgadea@unizar.es
}

\begin{abstract}
*We acknowledge the useful comments of an anonymous referee. We are also indebted to Pierre Perron and Zhongjun Qu, for their helpful suggestions. Financial support from Spanish Government CICYT projects ECO2008-03040 and ECO2009-13085 is recognised. The usual disclaimer applies.
\end{abstract}

(1) Fundear and Universidad de Zaragoza.

(2) Universidad de Zaragoza 
Keywords: oil shocks, inflation, production, structural breaks

JEL: C32, E23, E31, Q43

\begin{abstract}
This paper analyses the relationship between oil price shocks and the macroeconomic evolution of the G7 countries. Using the Qu and Perron (2007) methodology, we endogenously identify three breaks in the non-linear relationship across our 1970-2008 sample. We compute long-term multipliers and find that the response of output and inflation to oil price shocks is greatest in the 1970s and progressively disappears until the late 1990s. In contrast to the previous literature, we observe that both effects reappear in the 2000s, especially on inflation. Nevertheless, the transmission of oil price shocks to the economy is weaker than in the 1970s, which means that oil price shocks have lost some of their explanatory power. Precisely identifying these effects is crucial for the design of adequate economic measures to control or smoothen them.
\end{abstract}




\section{INTRODUCTION}

Since the mid 1960s, oil has been the most important primary energy source all over the world. Almost all economic activities are based on crude oil, which supplies around $40 \%$ of the world's total energy needs. The price of a barrel of crude oil is considered to be a point of reference, affecting the other energy markets. Moreover, shocks in crude oil prices do not only affect energy markets but also have an effect on the rest of the economy, even being able to influence the inflation rate, affect stock exchange prices and hinder economic growth.

There is a great deal of empirical research that analyses the effects of oil shocks on the economy due to their possible incidence on the real economy ${ }^{1}$. A survey of the effects of energy price shocks on the US economy is undertaken in Kilian (2008c) and a comprehensive review of the relationship between oil prices and the macroeconomy appears in Hamilton (2008) $)^{2}$.

Much of the literature has focused on the US, although some authors have recently examined the international impacts of oil shocks, mainly for the G7 countries. Some of these papers, more closely related to our research, focus on the evaluation of the relationship between oil price shocks and inflation and output since the 1970s. Jiménez-Rodríguez and Sánchez (2005) assesses the effects of oil price shocks on the economic activity of the eight main industrialised countries without dividing the relationship into different periods. Kilian (2008a) studies the differences and the

\footnotetext{
${ }^{1}$ This relation has been reported by Barsky and Kilian (2002, 2004), Baumeister and Peersman (2008), Bernanke et al. (1997), Blanchard and Galí (2008), Bohi (1989, 1991), Bruno and Sachs (1982), Davis and Haltiwanger (2001), Hamilton (1983, 1996, 2003, 2008), Hamilton and Herrera (2004), Hooker (1996, 2002), Kilian (2008a, 2008b), Lee and Ni (2002), Lee et al. (1995), Mork (1989), Mork et al. (1994) and Raymond and Rich (1997), amongst others.

${ }^{2}$ Furthermore, there are several papers that model the effects of oil price shocks on the theoretical side (see, e. g., Rotemberg and Woodford (1996), Finn (2000), Kilian (2009). More recently, there has been a renewed interest in DGSE models to investigate the effects of energy price shocks (see, e. g., Crucini et al. (2011), Nakov and Pescatori (2007), Blanchard and Galí (2008)). Another stream of literature considers the asymmetries caused by oil prices shocks on the US business cycle (see, e. g., Davis and Haltiwanger (2001), Clements and Krolzig (2002), Hamilton (1996, 2003), Hooker (1996, 2002)).
} 
similarities in the response of the G7 economies to exogenous oil supply shocks. Blanchard and Galí (2008) look for the components of macroeconomic fluctuations that are most associated with exogenous changes in oil prices for the G7 (except Canada) ${ }^{3}$. The main finding of these papers is a waning effect of oil price shocks since the 1980s.

In general, the empirical literature agrees that oil price shocks had an effect on the macroeconomy during the 1970s (exogenous events in OPEC countries may have caused recessions in industrialized countries through their effect on oil prices during the 1970s, as shown by the close statistical relationship between those events and recessions in the US). By contrast, this conclusion does not seem valid for the 1980s and 1990s and several authors maintain that the impact of oil price shocks on the macroeconomic variables has decreased and almost vanished since the mid $1980 \mathrm{~s}^{4}$.

The explanations for this change may be found in factors such as: the decrease of real wage rigidities that smoothens the trade-off between the stabilization of inflation and the stabilization of the output gap; the changes in monetary policy, adopting a commitment to a stable rate of inflation together with credibility gains; the decline of the oil share in the economy and today's higher energy efficiency that might decrease the effects of oil price variations; a reduction in the exchange rate pass-through; and, finally, that the current oil price shocks are associated with the strong global demand for crude oil ${ }^{5}$.

This stream of literature, related to what is known as “the Great Moderation”, provides some evidence in favour of a diminishing of the importance of oil shocks on economies. However, the recent movements in oil prices have cast some doubts on this

\footnotetext{
${ }^{3}$ Less directly linked, De Gregorio et al. compute IR analysis and rolling bivariate functions to check the pass-through of oil prices to inflation.

${ }^{4}$ See Blanchard and Galí (2008), De Gregorio et al. (2007), Edelstein and Kilian (2007, 2009) and Kapetanios and Tzavalis (2010), although the second one only studies the effects on inflation.

${ }^{5}$ For more details, see Bernanke et al. (1997), Blanchard and Galí (2008), De Gregorio et al. (2007), Kilian (2009) and Nakov and Pescatori (2007).
} 
lack of importance and reopened the debate about the influence of oil shocks on economies. Furthermore, the degree of this influence does not seem to be clear and, even more important, neither do the possible changes of the reactions of these economies to oil prices over time.

The aim of this paper is to determine the influence of oil shocks on the G7 economies (on inflation and economic growth) between 1970 and 2008, identifying different periods. This paper makes a contribution in testing for structural breaks in this relationship. We apply the recent technique of Qu and Perron (2007) which is devoted to finding structural breaks and allows them to be endogeneously determined by all the model parameters. Systematically assessing the magnitude, the length and the differences and similarities in the response of the G7 economies to exogenous oil price shocks is important to understand the historical economic record. Taking into account that, contrary to the empirical background, we find a resurgence of the influence of oil price shocks during the 2000s, a deeper study of the effects of oil price shocks is crucial for the design of adequate policy measures to control or smoothen the effects of future energy shocks on the economy.

The paper is organized as follows. Section 2 presents the methodology of Qu and Perron (2007) and the multipliers needed to assess the long-term and dynamic impact of oil price shocks on macroeconomic variables. Section 3 contains the main results in terms of break points and the effects of oil price shocks on each country's economic growth and CPI inflation rates. Section 4 concludes. 


\section{MULTIVARIATE REGRESSIONS: STRUCTURAL BREAKS AND MULTIPLIERS}

In this section, we present the method for detecting the presence of breaks in the relationship between G7 macroeconomic variables and oil price shocks. As has been mentioned earlier, to that end, we use the Qu and Perron (2007) methodology. The information obtained from the application of this method is subsequently employed to estimate the influence of oil shocks on the G7 economies. In order to measure this effect, two different tools are considered: the long-term multipliers, which enable us to check the magnitude and significance of the shock over the periods considered, and the dynamic multipliers, which allow us to examine the length and the graphic profile of the impacts. In what follows, all these concepts are discussed.

The Qu and Perron (2007) methodology has been designed to estimate and test for multiple structural changes that occur at unknown dates in a system of equations. A great advantage of this recent procedure is that changes may occur in the parameters of the conditional mean, the covariance matrix of the errors, or both jointly, and the distribution of the regressors is also allowed to change across regimes. The general model considered by these authors is as follows:

$$
y_{t}=\left(I \otimes z_{t}^{\prime}\right) S \beta_{j}+u_{t}
$$

There are $n$ equations and $T$ observations, excluding the initial conditions if lagged dependent variables are used as regressors. The total number of structural changes in the system is $m$ and the break dates are denoted by the $m$ vector $\mathrm{T}=\left(T_{1}, \ldots, T_{m}\right)$, taking into account that $T_{0}=1$ and $T_{m+1}=T$. A subscript $j$ indexes a regime ( $j=1, \ldots, m+1)$, a subscript $t$ indexes the temporal observation $(t=1, \ldots T)$, and a subscript $i$ indexes the equation $(i=1, \ldots n)$ to which a scalar dependent variable $y_{i t}$ is 
associated. The parameter $q$ is the number of regressors and $z_{t}$ is the set which includes the regressors from all the equations $z_{t}=\left(z_{1 t}, \ldots, z_{q t}\right)^{\prime}$. Furthermore, $u_{t}$ has mean 0 and covariance matrix $\sum_{j}$ for $T_{j+1}+1 \leq t \leq T_{j}$. This selection matrix involves elements that take the values 0 and 1 and, thus, indicate which regressors appear in each equation. When using a VAR model, we further have $z_{t}=\left(y_{t-1}, \ldots, y_{t-q}\right)$, which simply contains the lagged dependent variables and the deterministic terms, and $S$, which is an identity matrix.

This general framework must be adapted to the present case. In order to analyse the relationship between oil price shocks and some macroeconomic variables, the use of a VAR seems to be appropriate. We propose a bivariate VARX with two endogenous variables (GDP and CPI inflation) and an exogenous variable (OILP).

To decide on the number of lags, we have computed several information criteria starting with a maximum of 4 lags. In accordance with these results, the sample size and the significance of the lags for the full period and for each individual subperiod in each of the seven countries, we have chosen to impose 1 lag. Consequently, $z_{t}$ is defined as $\left(1, \Delta G D P_{t-1}, \Delta C P I_{t-1}, \Delta O I L P_{t}, \Delta O I L P_{t-1}\right)$ and $S=I_{10}$. The model can be expressed as follows:

$$
\begin{gathered}
Y_{t}=\alpha+\Phi Y_{t-1}+\Gamma_{0} X_{t}+\Gamma_{1} X_{t-1}+U_{t} \\
\text { where } Y_{t}=\left(\begin{array}{l}
\Delta G D P_{t} \\
\Delta C P I_{t}
\end{array}\right), X_{t}=\Delta O I L_{t}, \alpha=\left(\begin{array}{l}
\alpha_{1} \\
\alpha_{2}
\end{array}\right), \Phi=\left(\begin{array}{ll}
\beta_{11} & \delta_{11} \\
\beta_{21} & \delta_{21}
\end{array}\right), \Gamma_{0}=\left(\begin{array}{l}
\gamma_{10} \\
\gamma_{20}
\end{array}\right), \\
\Gamma_{0}=\left(\begin{array}{l}
\gamma_{10} \\
\gamma_{20}
\end{array}\right) \text { and } U_{0}=\left(\begin{array}{l}
u_{1} \\
u_{2}
\end{array}\right)
\end{gathered}
$$


From this system, the usual impulse response functions from $\triangle O I L P$ to both $\triangle G D P$ and $\triangle C P I$ can not be directly obtained. Nevertheless, given that it is necessary to estimate the expected response of macroeconomic aggregates to exogenous oil price shocks, long-run multipliers and dynamic multipliers are computed. We obtain our long-run multipliers from the lag-polynomials expression of the VARX:

$$
A(L) Y_{t}=\alpha+B(L) X_{t}+u_{t}
$$

where $A(L)^{-1} B(L)=\left(I_{2}-\Phi L\right)^{-1}\left(\Gamma_{0}+\Gamma_{1} L\right)$ and

$$
A(L)=1-\beta_{1} L-\beta_{2} L^{2}-\ldots, \quad B(L)=\gamma_{0}+\gamma_{1} L+\gamma_{2} L^{2}+\ldots
$$

Then,

$$
Y_{t}=A(L)^{-1} \alpha+A(L)^{-1} B(L) X_{t}+A(L)^{-1} u_{t}=A(L)^{-1} \alpha+D(L) X_{t}+A(L)^{-1} u_{t}
$$

The elements of the $D_{i}$ matrix mean the effect of a unit change in the exogenous variable on the endogenous variable $i$ periods ahead and are, therefore, called dynamic multipliers. The accumulated effects $\sum_{i=0}^{*} D_{t}$ represent the long-run effects or total multipliers ${ }^{6}$.

In addition, we test the significance of each set of multipliers. For the long-run multipliers we check it through a linear $F$ test, with the null hypothesis stated as:

$$
\begin{aligned}
& H_{0}: \sum_{i=0}^{2} \gamma_{1 i}=0 \text { for } \triangle \mathrm{GDP} \\
& \text { or } \\
& H_{0}: \sum_{i=0}^{2} \gamma_{2 i}=0 \text { for } \triangle \mathrm{CPI} \text { inflation }
\end{aligned}
$$

Confidence intervals at the $5 \%$ level have also been constructed by using standard bootstrap techniques for both the long-run multipliers and the dynamic

\footnotetext{
${ }^{6}$ For details, see Lütkepohl (2006).
} 
multipliers. We have generated 10,000 bootstrap replications of the parameters implicated. To do so, estimates of $\bar{\phi}, \mathrm{f}_{0}$ and $\mathrm{f}_{1}$ and bootstrap samples of residuals $\hat{\imath}_{1}$ and $\mathfrak{u}_{2}$, selected with replacement, have been employed. Finally, percentiles at 2.5 and 97.5 have been calculated from the bootstrap sampling distribution of the long-run and dynamic multipliers.

Several testing procedures are considered to determine the number of breaks in the system and jointly test changes in the coefficients and in the covariance matrix. First, we use the $U \operatorname{DmaLR}_{T}(M)$ and $W D \max L R_{T}(M)$ double maximum tests to see if at least one break is present. Then, if the test rejects this hypothesis, we consider a $S E Q_{T}(l+1 \mid l)$ sequential procedure obtained from a global maximization of the likelihood function and based on a test of $l$ versus $l+1$ changes and which tests for no change versus some unknown number up to some upper bound we impose. The number of breaks has been selected following critical values derived from response surface regressions ${ }^{7}$.

Because of our sample size $(T=151)$, we have carried out the procedure with a maximum number of breaks $m=3$ and a trimming of 0.2 , which means that the minimal length required is 30 observations $^{8}$. The covariance matrix of the errors is allowed to change and normality is assumed when testing for changes in the covariance matrix. We correct for serial correlation in the residuals and construct the robust covariate matrix by the method of Andrews (1991); no pre-whitening technique is applied. Finally, the distribution of the regressors is allowed to change in order to construct the confidence intervals. In all the countries, the tests offer evidence in favour of the presence of 3 breaks.

\footnotetext{
${ }^{7}$ Qu and Perron (2007).

${ }^{8}$ However, in the case of Italy, given the location of the breaks from the global optimization with 2 breaks, we need to reduce the trimming to 0.15 in order to locate the third break properly.
} 


\section{RESULTS}

To see the evolution of the price of oil since 1970, we use the Producer Price Index for crude petroleum and, from the monthly series, we construct a quarterly data set $^{9}$. We should also bear in mind the existence of a discussion in the literature related to the use of real or nominal oil prices. Following the view of Hamilton (2008), this paper uses the nominal oil price because the statistical exogeneity of the right-hand variables is important for interpreting the regression. The oil price is not converted into domestic currency for non-US countries for the same reason ${ }^{10}$.

To estimate the effects of oil price shocks on economic behaviour, the macro variables used are GDP, to measure production, and CPI inflation, to identify price evolution. Both are quarterly (measured quarter-to-quarter and expressed in annualized terms) and extracted from the OECD’s Economic Outlook database ${ }^{11}$. Our data set runs from 1970:I to 2008:IV and, thus, includes recent strong oil price shocks that are not considered by some previous studies. This wider span also allows us to analyse the end of one business cycle and explore the first steps of a new one, characterised by a deep world economic crisis.

The main results obtained from the application of the Qu-Perron methodology are reported in Table 1. First, we present the timing of the shocks and the different business cycles and, secondly, we comment on the impact of the oil price movements (long-term and dynamic multipliers) on the variables considered.

\footnotetext{
${ }^{9}$ Several calculations have been performed using the price of West Texas Intermediate crude; nevertheless, the timing of the breaks does not fit the business cycle as well. Bentzen (2007) finds bidirectional causality among the three major oil prices (Brent, OPEC and WTI).

${ }^{10}$ In this line, De Gregorio et al. (2007) find that, for a wide set of countries, there has been a reduction in the exchange rate pass-through of oil price to inflation.

${ }^{11}$ In the case of the UK, the CPI data have been extracted from the OECD’s Main Economic Indicators.
} 


\subsection{Location of breaks}

We identify four different periods in the relationship between oil price shocks and the G7 macroeconomic variables. The first interval covers the period between 1970 and the beginning of the 1980s (1980-1983). This period was characterised by the end of the long oil crisis. Two historical facts help to explain what happened during this period: first, the Arab-Israel war in 1973 which followed the long-lasting Arab-Israeli conflict; and, second, the Iranian revolution in 1978-79. During this period the economic growth of the seven countries considered was, in general, the highest of the four periods on average, except in the UK and the US, and inflation rates also attained their peak values, reaching two digit figures (Table 2).

The second period starts in the early 80 s and ends in the late 80 s-early $90 \mathrm{~s}^{12}$. The final data of the period is characterised by a slight recession that took place in 1989 in the US and a bit later in the EU (1992-1993). The economic growth rates decreased slowly compared to the first period but the decline of inflation rates was greater. Moreover, there were small oil price peaks, due to the long Iran-Iraq war (1980-88), which followed the Iranian revolution, and the Gulf war (1990-91).

The third period runs from around 1990 to a different date for each country between 1996 and 2001 ${ }^{13}$. In the years 2000-01, there was an almost worldwide minor downturn $^{14}$. CPI inflation was lower than in the first two periods and relatively stable. During this period there were no particular exogenous events related to oil price rises and drops, except in the countries in which the period ends at the beginning of the 2000s.

\footnotetext{
${ }^{12}$ In Italy, the second period is longer than in the other countries, ending in 1995 (see Rossi and Toniolo (1996) for a historical economic review of the first two periods).

${ }^{13}$ In most countries, this period finalises at the end of the century-beginning of the new one, but in Canada it ends earlier, in 1996.

${ }^{14}$ This lasted a little longer in the US due to the 9/11 terrorist attack but, nevertheless, the US economy reached its maximum mean growth on average in any of the periods.
} 
Finally, the last cycle ends in 2008 -when the international economic scenario was characterised by a major downturn in spite of the governments' policy measures to mitigate the adverse consequences of financial turmoil and when inflation rates began to diminish-, concluding a favourable cycle in terms of economic growth. In particular, during the last decade, there have been large movements (increases as well as decreases) in oil prices ${ }^{15}$. At the beginning of 1999, some oil price rises took place and reached their maximum in 2000 , coinciding with a time when the growth rate of the economy and world trade were particularly high (in Europe, the depreciation of the Euro also helped). The civil unrest in Venezuela influenced the oil shocks in 2002-2003, whilst the Iraq war, the Nigerian civil war and hurricane disasters in the Gulf of Mexico had an effect on oil price movements in 2003. In 2005, the world economy was characterised by high rates of growth and low inflation, despite the sharp rise of crude prices as a consequence of the surging demand from the most dynamic economies (China, India and the US) and the low level of excess oil production. In 2007, there was weak economic growth, inflationary tensions and financial instabilities; crude oil (as well as raw materials and food) prices continued to rise due to the strong demand from emerging countries and to speculation. In 2008, these prices began to fall ${ }^{16}$. During the whole of this period, movements in oil prices were greater in nominal terms and more persistent than in the first period.

\footnotetext{
${ }^{15}$ Jiménez-Rodríguez and Sánchez (2009) consider this as a period of high oil prices, that is, over which the oil price lies above the average of the series since 1970.

${ }^{16}$ In this recent period, speculation may have affected oil price swings even more than supply and demand changes. Oil is traded in the commodities futures market and it is held by speculative companies that consider it a shelter destiny. This futures market may have been responsible not only for the 2007 rises but also for the drastic drop in the price of oil during 2008, when it fell even more precipitously than it rose.
} 


\subsection{Effects of oil price shocks on the macroeconomic variables}

Having endogenously identified the different periods, we now calculate the effect of oil price shocks on the economies. We present the evidence on the responses of inflation and output to oil shocks in terms of sign, magnitude and significance, using long-term multipliers (see Table 3).

In the first period (from the early 1970s until 1980/83), the GDP multipliers exhibit negative values for all the seven countries as expected in the economic literature. These multipliers are not very high, although they are significant for three countries (Germany, Japan and the UK). The CPI multipliers are positive for six of the seven countries considered, but significant for the US, Canada, France, the UK and Italy. The result for the UK inflation should be highlighted because the CPI prices seem to overreact to the impact of the oil prices, obtaining a huge multiplier of $1.28^{17}$. The exception in sign for the CPI multiplier is the case of Japan, where a negative multiplier is found, but it is well known that the history of this country does not usually fulfil the standard premises ${ }^{18}$.

For the second period (1980/83 to 1987/95), we broadly obtain positive GDP multipliers, but the relationship between oil prices and output seems to be weaker than in the preceding period. In fact, these multipliers are only significant and positive for Canada and Germany, but very small. All CPI inflation multipliers are positive but only significant in the US, Japan and Italy and show a very reduced impact when compared to the first period studied.

\footnotetext{
${ }^{17}$ This could be related to the strong growth of the UK oil production and exports together with the decrease of imports during this period. In fact, the North Sea region began its production in 1975 and UK became a net exporter of oil in 1981, ending in 1984 when the increasing demand for oil made imports increase. Manning (1991) studies the relationship between retail petrol prices, excise duties and crude oil prices in the UK, finding asymmetries in the response only the first four months.

${ }^{18}$ Unexpected results for the Japanese economy are also found in Jiménez-Rodríguez and Sánchez (2005) and Blanchard and Galí (2008).
} 
In the third period (1987/95 to 1996/2001), significant GDP multipliers are identified in Canada, Germany and Italy. For the last two countries, the impact is positive and very low. For Canada, while the multiplier is negative, as expected, the value is unusually high (-0.29). In the case of prices, two significant CPI multipliers are found in Canada and Germany and are positive as expected. The value of the latter is small. However, in Canada, the value is similar to the one obtained in the first stage of the sample ${ }^{19}$. The evidence for the three periods shows that the estimated response of output and prices becomes weaker (smaller impact and less significant cases over time $)^{20}$.

Finally, for the fourth period (1996/2001 until 2008), which includes the most recent economic developments and sharp movements of oil prices, three significant GDP multipliers are found, for France, Japan and the UK. They are positive, except in the UK, and they all present a negligible value. Although oil price shocks recover some importance to explain output behaviour, only three significant multipliers still support the general idea of a decreasing impact of oil prices over time. However, the results for the CPI multipliers are more outstanding. They are broadly significant (in five cases: the US, Canada, France, the UK and Italy) and always positive. This means that, at least some of the recent inflation is explained, as in the first period, by the oil price swings. The main difference between these results and those obtained for the 1970s is the lower value of the multipliers found in the 2000s. The similarity in the averages of oil price changes in the first and the fourth periods, with an even stronger variability in the latter (the maximum and the minimum values differ by at least 140 points in the 2000s and by almost 80 in the 1970s), could explain this outcome (Table 2).

\footnotetext{
${ }^{19}$ Indeed, a glance at the Canadian series shows the asynchronous movements of these variables.

${ }^{20}$ A similar result was obtained by Blanchard and Galí (2008) and Kilian (2008a).
} 
In spite of this fact, due to the very small impact of the oil price shocks on the macroeconomic variables in the 2000s when it is significant, it is clear that the causes of higher inflation (and even more of GDP) should be sought elsewhere.

So far, we have analyzed the magnitude of the macroeconomic effects of oil price shocks and their change over the four periods identified. In a second stage, we assess the timing of the transmission of oil price shocks to the GDP and CPI inflation through the examination of dynamic multipliers (Figures 1). We only comment on the figures where significant long-term multipliers have been found. In general terms, and for both production and inflation, the key impact occurs in the first two quarters after the shock.

For the US economy, the CPI inflation dynamic multiplier is initially slight and positive in periods one, two and four (stronger in the first) and begins to vanish after two quarters and completely disappears after three years for the second and the fourth periods, while it lasts more than five years for the first.

In Canada, the smooth and positive impact on GDP in the second period only takes a year to completely disappear whilst the negative and strong effect in the third takes two years to vanish. Furthermore, the confidence intervals are unusually wide so the decreasing effects of the impact are very long-lasting. The responses of inflation in the first and third periods show a similar profile, with the peak reached at the second quarter and then disappearing after about three years. In the case of the fourth period, the greatest impact is at the moment of the shock and it completely vanishes after only a year, but the initial impact is smaller than in periods one and three.

French GDP responses to oil prices differ in the third and fourth periods. In the third, the shock causes a decrease that lasts more than five years with wide confidence bands, while the small positive effect in the fourth completely disappears after eight 
quarters. The CPI responses are significant in the first and the fourth periods, and both completely vanish after four years. In the first period, the decreasing profile diminishes smoothly while, in the fourth, the decrease in the second quarter is very sharp. In the fourth period, the initial magnitude is smaller.

For Germany, the dynamic multipliers of oil prices to GDP show contrary initial responses in periods one and three (slightly negative in the first and slightly positive in the third) but the impact of both disappears after ten quarters.

In Japan, the initial impact of the oil prices on the GDP is negative, but after quarter two, almost completely disappears. The dynamic multipliers of CPI inflation show different paths in the first, second and fourth periods and are always positive. The most similar profiles are found in the first and the fourth periods, although the initial impact is smaller in the latter. After the second quarter, the impacts begin to disappear but they take many years to do so completely. The confidence intervals are very wide and, in the first period, they even increase over time. In the second, the CPI response decreases smoothly over time, vanishing after four years.

The GDP dynamic multiplier for the UK is small and has a negative initial effect in the first period. In period four, where it is also negative and very slight, it takes many years to completely disappear. The very positive CPI response in the first period reaches its peak in the second quarter and takes a long time to completely vanish. The same occurs in the fourth period, but the initial effect is smaller and then decreases gradually.

Finally, in the Italian economy, the GDP dynamic multiplier shows a tiny positive impact in the first two quarters of period three, then it progressively decreases and completely disappears after three years. The response of CPI inflation is significant in periods one, two and four. In all three, it completely disappears after three years. The first shows the greatest impact in the first two quarters while, in the second and the 
fourth, the initial positive impact is smaller and begins to decrease in the second quarter (the confidence intervals are broader in periods two and four).

Overall, the timing paths differ substantially across countries and variables. The results for the dynamic multipliers broadly confirm the peculiar behaviour of oil price transmission not only in the 1970s but also in the 2000s.

\section{FINAL REMARKS}

This paper estimates the impact of oil price shocks on the economic activity and prices of the G7 countries. The Qu and Perron methodology offers evidence of a nonlinear relationship, identifying four differentiated periods for the sample 1970-2008. This initial result is quite important because, although previous literature has found a change in the reaction of economies to changes in oil shocks, neither the existence of these breaks nor their location had previously been endogenously verified.

Having proved the existence of the breaks, we estimate the influence of oil price shocks for the different periods. We find that, whereas the evidence of a temporary reduction in the response of output and prices across all seven countries becomes weaker from the 1970s (when it reaches its greatest responses) until the late 1990s, from then on, the response is less clear-cut. Indeed, and in clear contrast to the previous research, in the last period (that covers the 2000s), the impact of oil prices on the macroeconomic variables (mainly, on prices) recovers some of its initial importance (however, the impact is smaller than in the 1970s). Moreover, the examination of dynamic multipliers shows that the main impact of oil price shocks, on both production and inflation, occurs in the first two quarters after the shock, but the timing paths are very different across countries. 
An adequate and precise characterization of the features studied in this paper (magnitude, length and differences in the response of G7 countries growth and prices to oil price shocks) is crucial for the implementation of policy measures to control or smoothen the effects of future oil price shifts. Our results open a line of future research focused on the identification of the possible causes of the revival of the impact of oil prices shocks and their channels of transmission. 


\section{REFERENCES}

Andrews, D.W. K. (1991). "Heteroskedasticity and Autocorrelation Consistent Covariance Matrix Estimation”, Econometrica, 59, 817-858.

Barsky, R. B., and L. Kilian (2002). "Do We Really Know that Oil Caused the Great Stagflation? A Monetary Alternative” in B. S. Bernanke and K. Rogoff (eds.), NBER Macroeconomics Annual 2001, MIT Press.

Barsky, R. B., and L. Kilian (2004). “Oil and the Macroeconomy since the 1970s”, Journal of Economic Perspectives, 18(4), 115-134.

Baumeister, C. and G. Peersman (2008). Time-Varying Effects of Oil Supply Shocks on the US economy, Working Papers of Faculty of Economics and Business Administration, Ghent University, Belgium.

Bentzen, J. (2007). "Does OPEC influence crude oil prices? Testing for co-movements and causality between regional crude oil prices," Applied Economics, 39(11), 1375-1385.

Bernanke, B. S., M. Gertler, and M. W. Watson (1997). "Systematic Monetary Policy and the Effects of Oil Price Shocks”, Brookings Papers on Economic Activity, 1, 91-157.

Blanchard, O. J. and J. Galí (2008). "The macroeconomic effects of oil price shocks: Why are the 2000s so different from the 1970s?” in J. Galí and M. Gertler (eds.), International Dimensions of Monetary Policy, University of Chicago Press (Chicago, IL).

Bohi, D. R. (1989). Energy Price Shocks and Macroeconomic Performance, Resources for the Future.

Bohi, D. R. (1991). “On the Macroeconomic Effects of Energy Price Shocks”, Resources and Energy, 13, 145-162.

Bruno, M., and J. Sachs (1982). "Input Price Shocks and the Slowdown in Economic Growth: The Case of U.K. Manufacturing”, Review of Economic Studies, 49, 679-705.

Clements, M. P. and H-M. Krolzig (2002). "Can oil shocks explain asymmetries in the US Business Cycle?”, Empirical Economics, 27, 185-204. 
Crucini, M. J., Kose, M. A. and C. Otrok (2011). "What are the driving forces of international business cycles?”, Review of Economic Dynamics, 14(1), 156-175.

Davis, S. J., and J. Haltiwanger (2001). "Sectoral Job Creation and Destruction Responses to Oil Price Changes” Journal of Monetary Economics, 48, 465-512.

De Gregorio, J., Landerretche, O. and C. Neilson (2007). “Another Pass-Through Bites the Dust? Oil prices and Inflation”, Economia, 7(2), 155-196.

Edelstein, P. and L. Kilian (2007). "The Response of Business Fixed Investment to Changes in Energy Prices: A Test of Some Hypotheses about the Transmission of Energy Price Shocks”, B. E. Journal of Macroeconomics, 7(1).

Edelstein, P. and L. Kilian (2009). "How Sensitive are Consumer Expenditures to Retail Energy Prices?”, Journal of Monetary Economics, 56(6), 766-779.

Finn, M. G. (2000). "Perfect Competition and the Effects of Energy Price Increases on Economic Activity”, Journal of Money, Credit and Banking, 32(3), 400-416.

Hamilton, J. D. (1983). “Oil and the Macroeconomy since World War II”, Journal of Political Economy, 91, 228-248.

Hamilton, J. D. (1996). “This Is What Happened to the Oil-Macroeconomy Relationship”, Journal of Monetary Economics, 38(2), 215-220.

Hamilton, J. D. (2003). “What Is an Oil Shock?”, Journal of Econometrics, 113, 363-398.

Hamilton, J. D. (2008). Oil and the Macroeconomy, in Durlauf, S. N. and L. E. Blume (eds.), The New Palgrave Dictionary of Economics, Second Ed, Houndmills, UK and New York, Palgrave Macmillan.

Hamilton, J. D., and A. Herrera (2004). "Oil Shocks and Aggregate Macroeconomic Behavior: The Role of Monetary Policy”, Journal of Money, Credit and Banking, 36, 265-286.

Hooker, M. A. (1996). “What Happened to the Oil-Macroeconomy Relationship?”, Journal of Monetary Economics, 38, 195-213.

Hooker, M. A. (2002). “Are Oil Shocks Inflationary? Asymmetric and Nonlinear Specifications versus Changes in Regime”, Journal of Money, Credit and Banking, 34, 540-561. 
Jiménez-Rodríguez, R., and M. Sánchez (2005). “Oil Price Shocks and Real GDP Growth: Empirical Evidence for Some OECD Countries”, Applied Economics, 37, 201-228.

Jiménez-Rodríguez, R., Sánchez, M. (2009). “Oil shocks and the macroeconomy: A comparison across high oil price periods”, Applied Economics Letters, 16, 1633-1638.

Kilian, L. (2009). "Not All Oil Price Shocks Are Alike: Disentangling Demand and Supply Shocks in the Crude Oil Market”, American Economic Review, 99(3), 1053-1069.

Kapetanios, G. and E. Tzavalis (2010). "Modeling Structural Breaks in Economic Relationships Using Large Shocks”, Journal of Economic Dynamics and Control, 34(3), 417-436.

Kilian, L. (2008a). "A comparison of the effects of exogenous oil supply shocks on output and inflation in the G7 countries", Journal of the European Economic Association, 6(1), 78121.

Kilian, L. (2008b). "Exogenous Oil Supply Shocks: How Big Are They and How Much Do They Matter for the U.S. Economy?”, Review of Economics and Statistics, 90(2), 216240.

Kilian, L. (2008c). “The Economic Effects of Energy Price Shocks”, Journal of Economic Literature, 46(4), 871-909.

Kilian, L., A. Rebucci and N. Spatafora (2009). “Oil Shocks and External Balances”, Journal of International Economics, 77(2), 181-194.

Lee, K., and S. Ni (2002). "On the Dynamic Effects of Oil Price Shocks: A Study Using Industry Level Data”, Journal of Monetary Economics, 49(4), 823-852.

Lee, K., S. Ni, and R. Ratti (1995). "Oil Shocks and the Macroeconomy: The Role of Price Variability”, Energy Journal, 16, 39-56.

Lütkepohl, H. (2006). New Introduction to Multiple Time Series Analysis. Berlin: Springer Verlag.

Manning, D. M. (1991). "Petrol Prices, Oil Price Rises and Oil Price Falls: Some Evidence for the UK since 1972”, Applied Economics, 23( 9), 1535-41.

Mork, K. A. (1989). “Oil and the Macroeconomy when Prices Go Up and Down: An Extension of Hamilton's Results”, Journal of Political Economy, 91, 740-744. 
Mork, K. A., Ø. Olsen, and H. T. Mysen (1994). "Macroeconomic Responses to Oil Price Increases and Decreases in Seven OECD Countries”, Energy Journal, 15, 15-38.

Nákov, A. and A. Pescatori (2007). “Oil and the Great Moderation”, Economic Journal, 120 (543), 131-156.

Qu, Z. and P. Perron (2007). "Estimating and Testing Structural Changes in Multivariate Regressions" Econometrica, 75(2), 459-502.

Raymond, J. E. and R. W. Rich (1997). “Oil and the macroeconomy: A Markov state-switching approach”, Journal of Money, Credit and Banking, 29, 193-213.

Rossi, N. and G. Toniolo (1996). "Italy”, in Crafts, N. and G. Toniolo (ed.), Economic growth in Europe since 1945, CEPR, Cambridge University Press, 427-454.

Rotemberg, J. and M. Woodford (1996). "Imperfect Competition and the Effects of Energy Price Increases on Economic Activity”, Journal of Money, Credit and Banking, 28(4), 549-577. 
TABLES AND FIGURES

Table 1. Analysis of structural breaks (Qu and Perron methodology)

\begin{tabular}{|c|c|c|c|c|}
\hline & \multirow[t]{2}{*}{ Wdmax } & \multicolumn{2}{|c|}{ Sequential test $(I+1 / /)$} & \multirow{2}{*}{$\begin{array}{c}\text { Number of } \\
\text { breaks }\end{array}$} \\
\hline & & $\mathrm{l}=1$ & $I=2$ & \\
\hline US & $126.732^{\star \star \star}$ & $32.634^{\star}$ & $46.853^{\star \star \star}$ & 3 \\
\hline CANADA & $89.843^{\star \star *}$ & $44.991^{\star \star \star *}$ & $43.294^{\star \star \star}$ & 3 \\
\hline FRANCE & $139.490^{* \star *}$ & $48.133^{\star \star \star}$ & 35.896 ** & 3 \\
\hline GERMANY & $52.133^{\star \star \star}$ & $49.834^{\star * *}$ & 29.109 & 3 \\
\hline JAPAN & $188.207^{\star \star \star}$ & $41.043^{\star * \star}$ & 27.185 & 3 \\
\hline UK & $242.066^{\star \star \star}$ & $63.006^{\star \star \star}$ & $63.448^{\star \star \star}$ & 3 \\
\hline ITALY & $230.464^{\star \star \star}$ & $107.333^{\star \star \star}$ & $107.333^{\star * \star}$ & 3 \\
\hline
\end{tabular}

Notes:

(1) $M=3$ for every country. (2) Trimming=0.20, except in Italy where trimming $=0.15$. (3) $T=151$. (4) The covariance matrix of the errors is allowed to change. Normality is assumed when testing changes in the covariance matrix. (5) Serial correlation in the residuals is corrected and the robust covariate matrix is constructed by the method of Andrews (1991), but no pre-whitening technique is applied. (6) The distribution of the regressors is allowed to change in order to construct confidence intervals.

* significant at $10 \%$; ** significant at $5 \%$; *** significant at $1 \%$. 
Table 2. Descriptive Statistics (1970:01-2008:04)

\begin{tabular}{|c|c|c|c|c|c|c|c|c|c|c|c|c|c|c|c|}
\hline & \multicolumn{4}{|c|}{ PERIOD 1} & \multicolumn{4}{|c|}{ PERIOD 2} & \multicolumn{4}{|c|}{ PERIOD 3} & \multicolumn{3}{|c|}{ PERIOD 4} \\
\hline & mean & $\begin{array}{c}\text { max. } \\
\text { change }\end{array}$ & $\begin{array}{c}\text { min. } \\
\text { change }\end{array}$ & TB I & mean & $\begin{array}{l}\text { max. } \\
\text { change }\end{array}$ & $\begin{array}{c}\text { min. } \\
\text { change }\end{array}$ & TB ॥ & mean & $\begin{array}{c}\text { max. } \\
\text { change }\end{array}$ & $\begin{array}{c}\text { min. } \\
\text { change }\end{array}$ & TB III & mean & $\begin{array}{c}\text { max. } \\
\text { change }\end{array}$ & $\begin{array}{c}\text { min. } \\
\text { change }\end{array}$ \\
\hline \multicolumn{16}{|l|}{ GDP growth } \\
\hline US & 2.87 & 7.72 & -2.71 & 1983:04 & 3.52 & 8.49 & -1.00 & 1991:03 & 3.59 & 4.79 & 1.09 & 1999:04 & 2.43 & 4.85 & 0.13 \\
\hline CANADA & 4.06 & 8.40 & 0.66 & 1981:02 & 3.16 & 6.55 & -3.71 & 1988:04 & 1.60 & 5.43 & -3.37 & 1996:02 & 3.14 & 5.93 & -0.51 \\
\hline FRANCE & 3.48 & 5.74 & -1.32 & 1980:02 & 1.77 & 3.52 & -0.40 & 1987:04 & 2.09 & 4.88 & -1.05 & 1998:01 & 2.17 & 4.66 & -0.08 \\
\hline GERMANY & 2.99 & 7.08 & -2.33 & 1980:03 & 2.50 & 6.78 & -1.31 & 1992:04 & 1.74 & 4.71 & -1.95 & 2000:04 & 1.25 & 4.14 & -0.53 \\
\hline JAPAN & 4.43 & 10.23 & -2.07 & 1981:01 & 3.86 & 7.17 & 0.99 & 1992:01 & 0.82 & 3.65 & -2.65 & 1999:03 & 1.56 & 3.96 & -1.84 \\
\hline UK & 1.70 & 9.99 & -4.11 & 1982:01 & 2.75 & 5.98 & -2.17 & 1991:04 & 2.91 & 4.83 & -0.47 & 2000:01 & 2.48 & 4.53 & -0.75 \\
\hline ITALY & 2.98 & 9.85 & -3.68 & 1983:03 & 2.39 & 4.69 & -1.46 & 1995:04 & 1.96 & 4.12 & -0.14 & 2001:03 & 0.75 & 2.47 & -0.86 \\
\hline \multicolumn{16}{|l|}{ CPI inflation } \\
\hline US & 7.56 & 14.42 & 2.52 & 1983:04 & 4.03 & 6.28 & 1.35 & 1991:03 & 2.57 & 3.23 & 1.48 & 1999:04 & 2.95 & 5.27 & 1.23 \\
\hline CANADA & 8.27 & 12.52 & 1.32 & 1981:02 & 5.84 & 12.70 & 3.62 & 1988:04 & 2.91 & 6.44 & -0.04 & 1996:02 & 2.10 & 4.48 & 0.77 \\
\hline FRANCE & 9.47 & 15.01 & 4.85 & 1980:02 & 8.13 & 14.11 & 2.10 & 1987:04 & 2.34 & 3.62 & 0.71 & 1998:01 & 1.71 & 3.30 & 0.27 \\
\hline GERMANY & 5.08 & 7.48 & 2.49 & 1980:03 & 2.96 & 7.12 & -0.92 & 1992:04 & 1.90 & 4.61 & 0.26 & 2000:04 & 1.77 & 3.07 & 0.83 \\
\hline JAPAN & 9.07 & 23.47 & 3.08 & 1981:01 & 2.05 & 4.71 & -0.98 & 1992:01 & 0.72 & 2.24 & -0.53 & 1999:03 & -0.17 & 1.96 & -1.40 \\
\hline UK & 13.58 & 26.57 & 6.18 & 1982:01 & 5.42 & 9.35 & 2.62 & 1991:04 & 2.28 & 7.00 & 0.80 & 2000:01 & 1.84 & 4.81 & 0.61 \\
\hline ITALY & 14.53 & 24.69 & 4.70 & 1983:03 & 6.29 & 12.74 & 3.82 & 1995:04 & 2.51 & 5.18 & 1.39 & 2001:03 & 2.39 & 3.97 & 1.59 \\
\hline \multicolumn{16}{|l|}{ OIL PRICES } \\
\hline US & 17.45 & 74.90 & -13.80 & 1983:04 & 0.64 & 68.34 & -54.09 & 1991:03 & 0.09 & 111.28 & -42.86 & 1999:04 & 26.88 & 170.46 & -43.26 \\
\hline CANADA & 21.39 & 74.90 & -1.28 & 1981:02 & -5.70 & 54.45 & -54.09 & 1988:04 & 4.38 & 68.34 & -37.07 & 1996:02 & 20.78 & 170.46 & -43.26 \\
\hline FRANCE & 18.32 & 74.90 & -1.28 & 1980:02 & 2.64 & 54.45 & -54.09 & 1987:04 & 1.69 & 68.34 & -37.07 & 1998:01 & 24.09 & 170.46 & -43.26 \\
\hline GERMANY & 19.40 & 74.90 & -1.28 & 1980:03 & 2.27 & 68.34 & -54.09 & 1992:04 & 12.33 & 170.46 & -42.86 & 2000:04 & 19.85 & 100.23 & -43.26 \\
\hline JAPAN & 20.59 & 74.90 & -1.28 & 1981:01 & 0.48 & 68.34 & -54.09 & 1992:01 & -1.56 & 72.43 & -42.86 & 1999:03 & 29.16 & 170.46 & -43.26 \\
\hline UK & 21.48 & 74.90 & -3.68 & 1982:01 & -1.96 & 68.34 & -54.09 & 1991:04 & 6.38 & 170.46 & -42.86 & 2000:01 & 22.78 & 100.23 & -43.26 \\
\hline ITALY & 17.94 & 74.90 & -13.80 & 1983:03 & -1.62 & 68.34 & -54.09 & 1995:04 & 17.32 & 170.46 & -42.86 & 2001:03 & 22.89 & 100.23 & -43.26 \\
\hline
\end{tabular}

*Data obtained from the Economic Outlook, 84 (OECD), UK CPI from the MEI (OECD).

Editorial Office, Dept of Economics, warwick University, Coventry CV4 7AL, UK 
Table 3. Long-term multipliers on GDP and CPI inflation (1970:01-2008:04)

\begin{tabular}{|c|c|c|c|c|c|c|c|c|c|c|c|}
\hline & $\mathrm{LM}_{\mathrm{GDP}}$ & $\mathrm{LM}_{\mathrm{CPI}}$ & TB I & $L_{\mathrm{GDP}}$ & $\mathrm{LM}_{\mathrm{CPI}}$ & TB II & $\mathrm{LM}_{\mathrm{GDP}}$ & $\mathrm{LM}_{\mathrm{CPI}}$ & TB III & $L_{\mathrm{GDP}}$ & $\mathrm{LM}_{\mathrm{CPI}}$ \\
\hline US & $\begin{array}{c}-0.01 \\
(-0.11,0.09)\end{array}$ & $\begin{array}{c}0.33^{\star \star *} \\
(0.10,0.91)\end{array}$ & 1983:04 & $\begin{array}{c}0.07 \\
(-0.04,0.26)\end{array}$ & $\begin{array}{c}0.05^{\star \star \star} \\
(0.02,0.09)\end{array}$ & 1991:03 & $\begin{array}{c}0.00 \\
(-0.02,0.02)\end{array}$ & $\begin{array}{c}0.02 \\
(-0.04,0.09)\end{array}$ & 1999:04 & $\begin{array}{c}0.02 \\
(-0.01,0.06)\end{array}$ & $\begin{array}{c}0.04^{\star \star \star} \\
(0.02,0.08)\end{array}$ \\
\hline CANADA & $\begin{array}{c}-0.03 \\
(-0.07,0.01)\end{array}$ & $\begin{array}{c}0.11^{\star \star \star} \\
(0.06,0.16)\end{array}$ & 1981:02 & $\begin{array}{c}0.07^{\star \star \star} \\
(0.03,0.10)\end{array}$ & $\begin{array}{c}0.34 \\
(-1.90,1.95)\end{array}$ & 1988:04 & $\begin{array}{c}-0.29 * \star \star \\
(-0.99,-0.06)\end{array}$ & $\begin{array}{c}0.17^{\star \star \star} \\
(0.09,0.27)\end{array}$ & 1996:02 & $\begin{array}{c}0.01 \\
(-0.05,0.06)\end{array}$ & $\begin{array}{c}0.02^{\star \star} \\
(0.01,0.03)\end{array}$ \\
\hline FRANCE & $\begin{array}{c}-0.01 \\
(-0.05,0.04)\end{array}$ & $\begin{array}{c}0.21^{\star \star \star} \\
(0.13,0.37)\end{array}$ & 1980:02 & $\begin{array}{c}0.05^{\star} \\
(-0.01,0.09)\end{array}$ & $\begin{array}{c}0.04 \\
(-0.13,0.25)\end{array}$ & 1987:04 & $\begin{array}{c}-0.35^{\star \star \star} \\
(-1.13,0.62)\end{array}$ & $\begin{array}{c}0.00 \\
(-0.14,0.17)\end{array}$ & 1998:01 & $\begin{array}{c}0.02^{\star \star \star} \\
(0.01,0.03)\end{array}$ & $\begin{array}{c}0.04^{\star \star} \\
(0.01,0.08)\end{array}$ \\
\hline GERMANY & $\begin{array}{c}-0.09^{* * *} \\
(-0.14,-0.03)\end{array}$ & $\begin{array}{c}0.01 \\
(-0.12,0.13)\end{array}$ & 1980:03 & $\begin{array}{c}0.05^{\star} \\
(0.00,0.11)\end{array}$ & $\begin{array}{c}0.15^{\star} \\
(-0.14,0.49)\end{array}$ & 1992:04 & $\begin{array}{c}0.02^{\star *} \\
(0.01,0.04)\end{array}$ & $\begin{array}{c}0.04^{\star} \\
(0.00,0.13)\end{array}$ & 2000:04 & $\begin{array}{c}0.03 \\
(-0.04,0.12)\end{array}$ & $\begin{array}{c}0.01 \\
(-0.00,0.02)\end{array}$ \\
\hline JAPAN & $\begin{array}{c}-0.09^{\star * *} \\
(-0.15,-0.03)\end{array}$ & $\begin{array}{c}-0.62^{\star \star \star} \\
(-5.82,4.67)\end{array}$ & 1981:01 & $\begin{array}{c}0.04 \\
(-0.01,0.08)\end{array}$ & $\begin{array}{c}0.06^{\star \star *} \\
(0.02,0.10)\end{array}$ & 1992:01 & $\begin{array}{c}0.03 \\
(-0.01,0.08)\end{array}$ & $\begin{array}{c}-0.01 \\
(-0.05,0.03)\end{array}$ & 1999:03 & $\begin{array}{c}0.03^{\star} \\
(0.00,0.06)\end{array}$ & $\begin{array}{c}0.05^{\star \star} \\
(-0.01,0.19)\end{array}$ \\
\hline UK & $\begin{array}{c}-0.09^{\star \star *} \\
(-0.13,-0.04)\end{array}$ & $\begin{array}{c}1.28^{\star \star \star} \\
(0.09,3.95)\end{array}$ & 1982:01 & $\begin{array}{c}-0.01 \\
(-0.07,0.03)\end{array}$ & $\begin{array}{c}0.02 \\
(-0.01,0.04)\end{array}$ & 1991:04 & $\begin{array}{c}0.00 \\
(-0.01,0.01)\end{array}$ & $\begin{array}{c}0.00 \\
(-0.01,0.01)\end{array}$ & 2000:01 & $\begin{array}{c}-0.05^{\star \star} \\
(-0.12,-0)\end{array}$ & $\begin{array}{c}0.09^{\star * \star} \\
(0.01,0.26)\end{array}$ \\
\hline ITALY & $\begin{array}{c}-0.09 \\
(-0.24,0.04)\end{array}$ & $\begin{array}{c}0.16 \\
(0.01,0.32)\end{array}$ & 1983:03 & $\begin{array}{c}-0.05 \\
(-0.15,0.02)\end{array}$ & $\begin{array}{c}0.09^{\star \star \star} \\
(0.04,0.15)\end{array}$ & 1995:04 & $\begin{array}{c}0.03^{\star \star} \\
(0.01,0.05)\end{array}$ & $\begin{array}{c}0.00^{\star} \\
(-0.00,0.01)\end{array}$ & 2001:03 & $\begin{array}{c}-0.02 \\
(-0.06,0.01)\end{array}$ & $\begin{array}{c}0.04^{\star \star \star} \\
(0.01,0.10)\end{array}$ \\
\hline
\end{tabular}

Data obtained from the Economic Outlook, 84 (OECD), UK and Spanish CPI from the MEI (OECD).

TB means time of break.

In brackets, confidence intervals obtained from a bootstrap technique with the significance level at 5\%.

For a linear F test: * significant at 10\%; ** significant at 5\%; *** significant at $1 \%$. 


\section{Figures 1. Dynamic multipliers of OIL prices to GDP and to CPI inflation}

\section{$\underline{\text { US }}$}
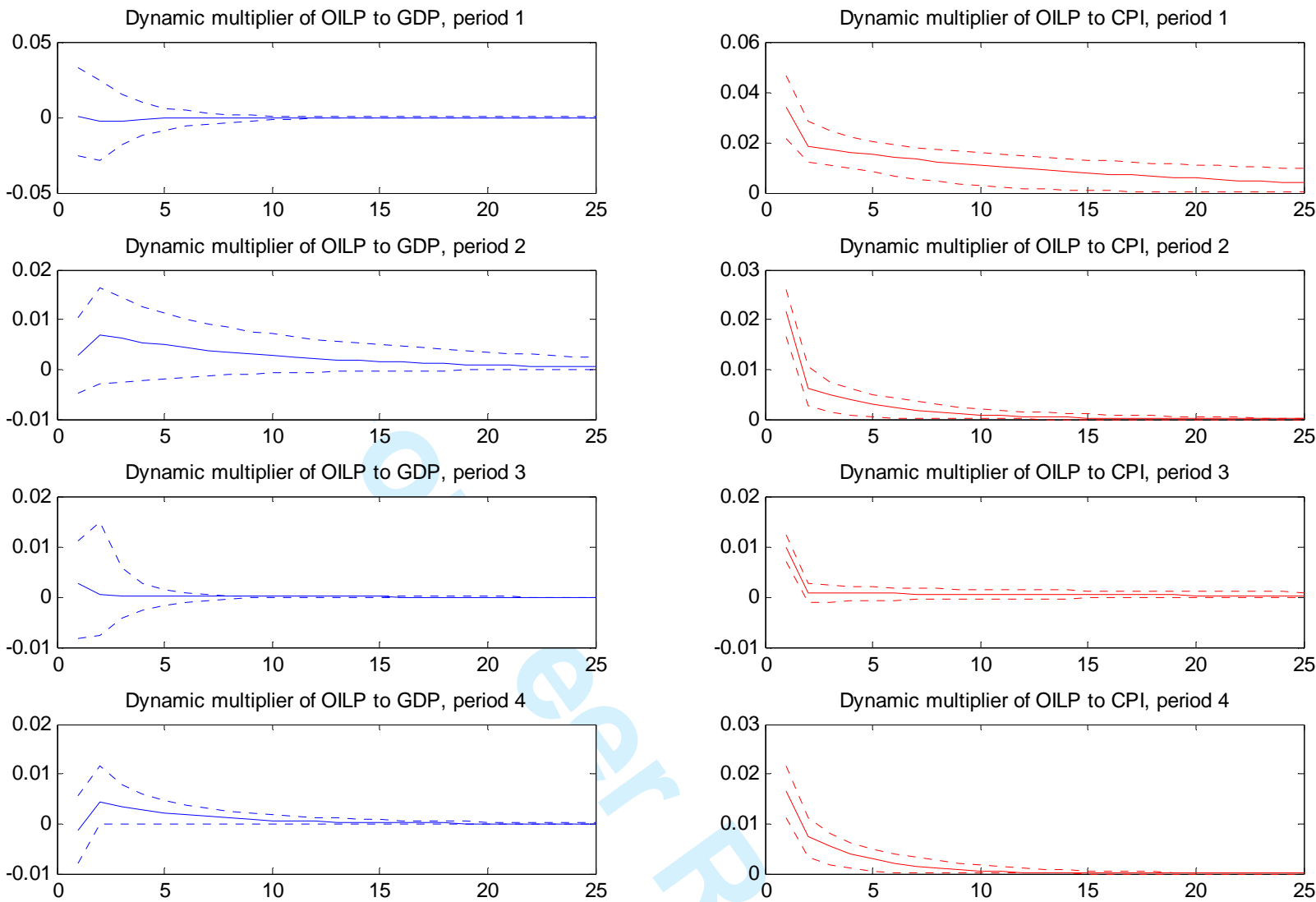


\section{CANADA}
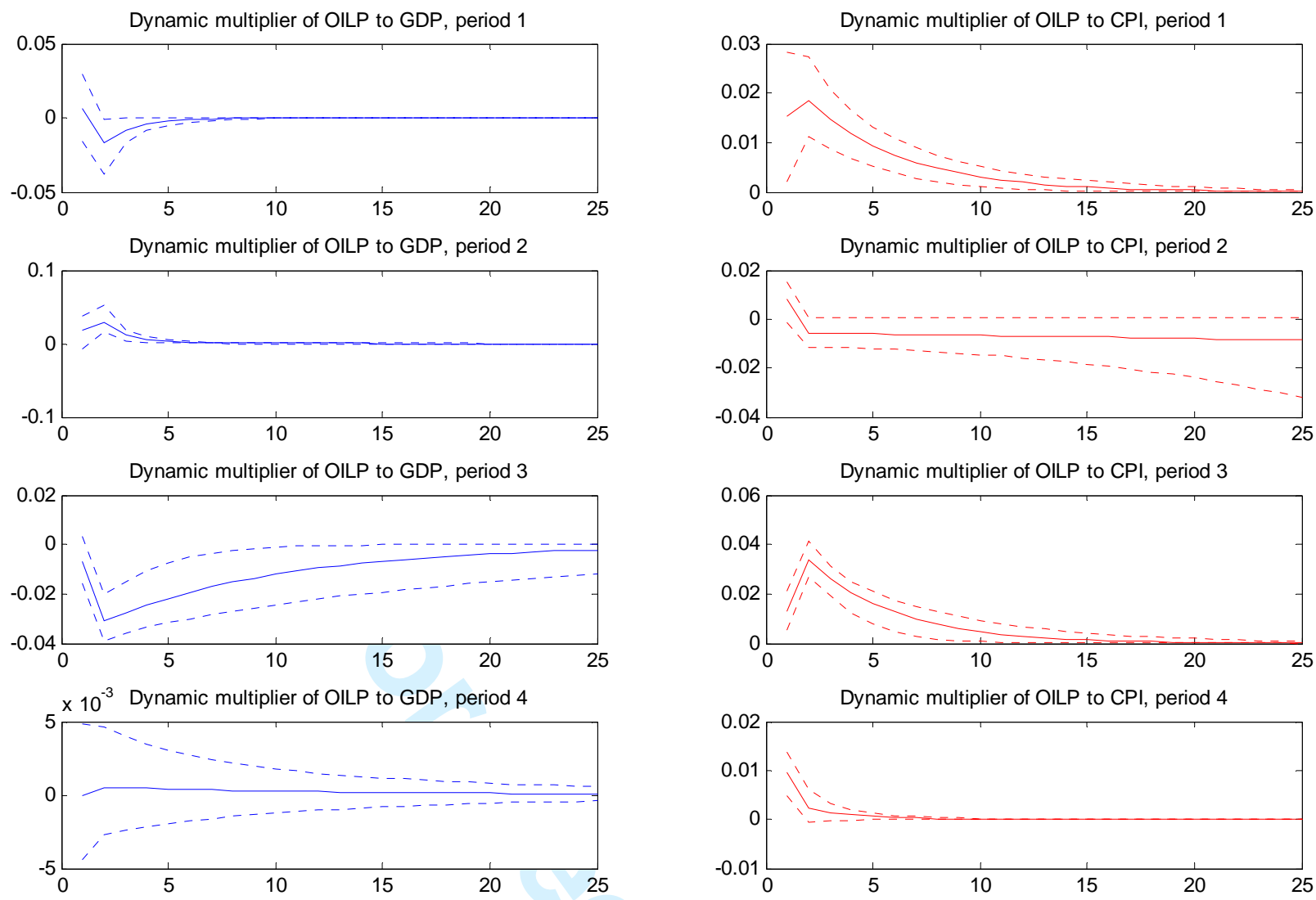

FRANCE
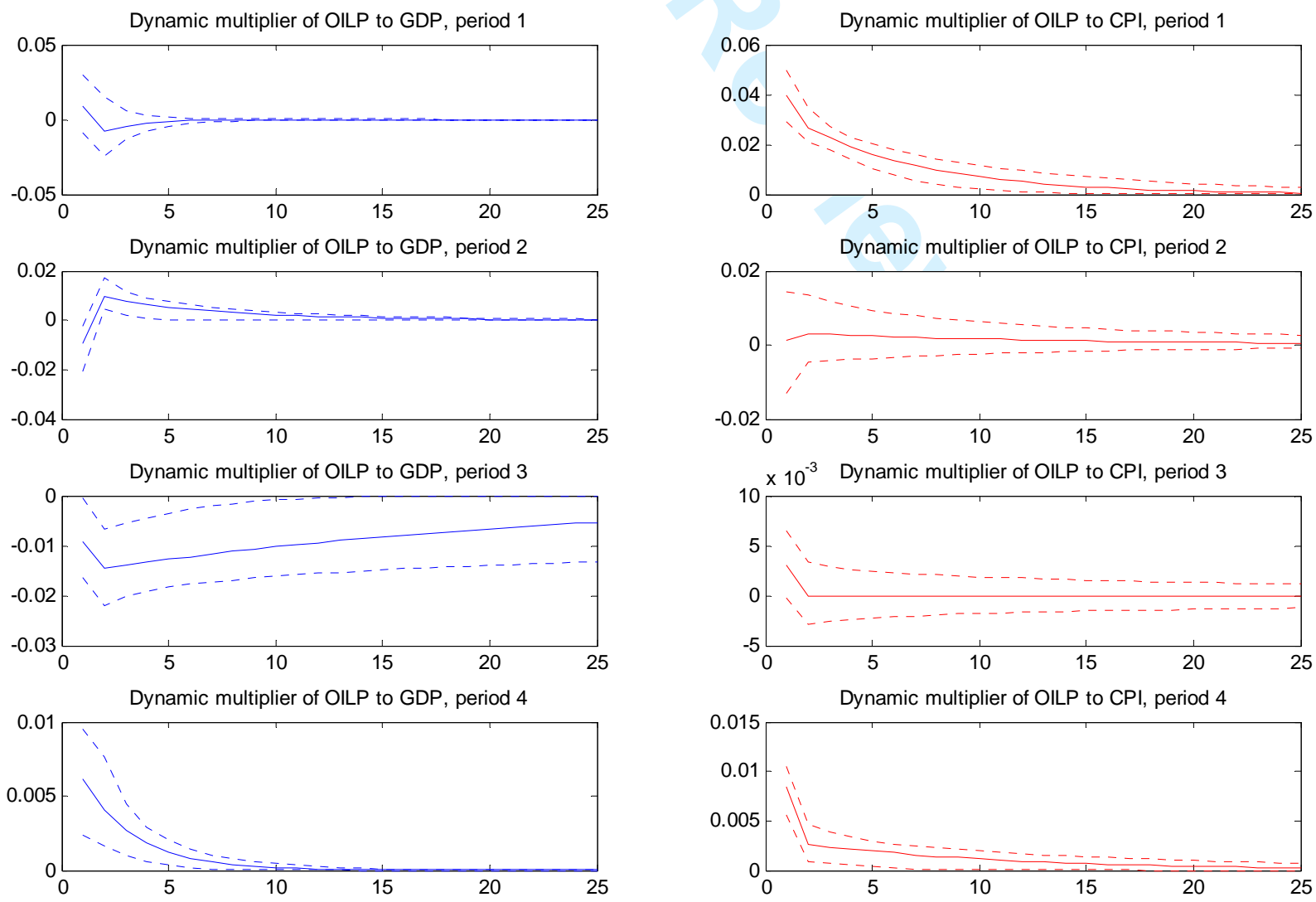

Editorial Office, Dept of Economics, warwick University, Coventry CV4 7AL, UK 


\section{GERMANY}
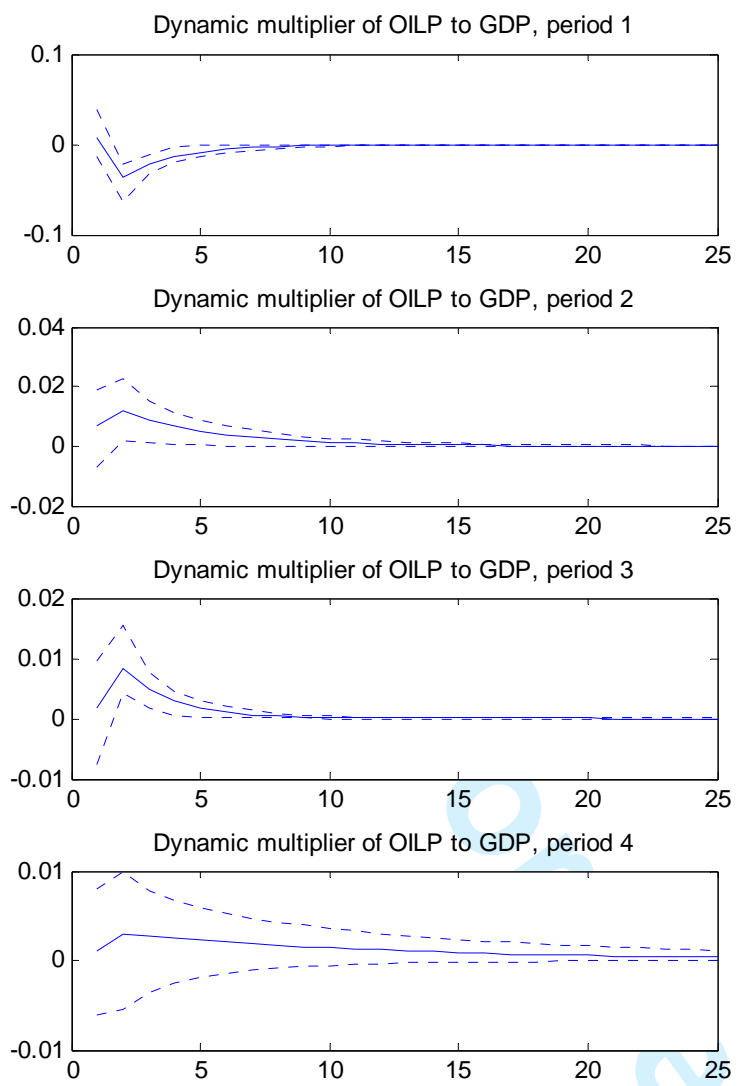

\section{JAPAN}
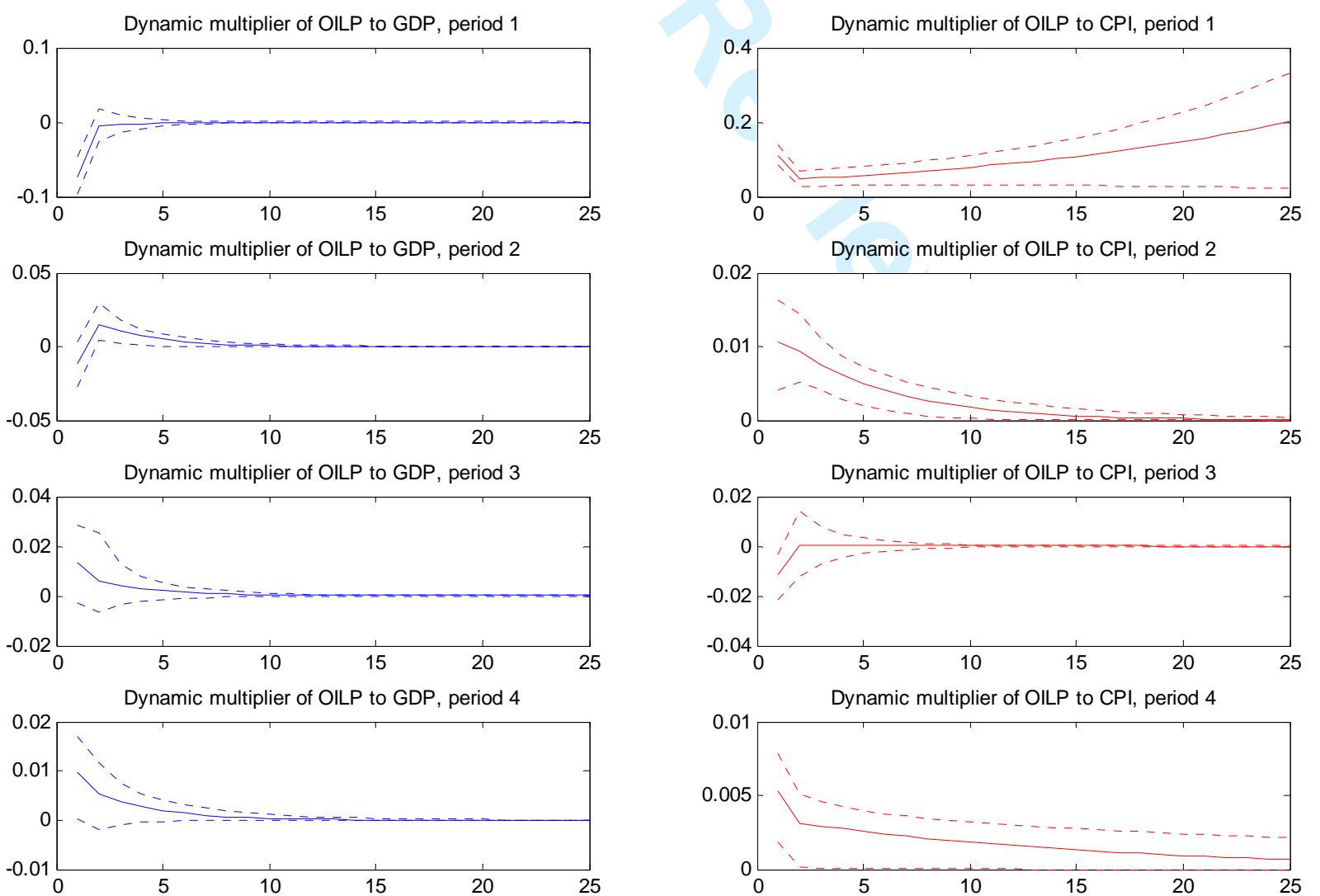

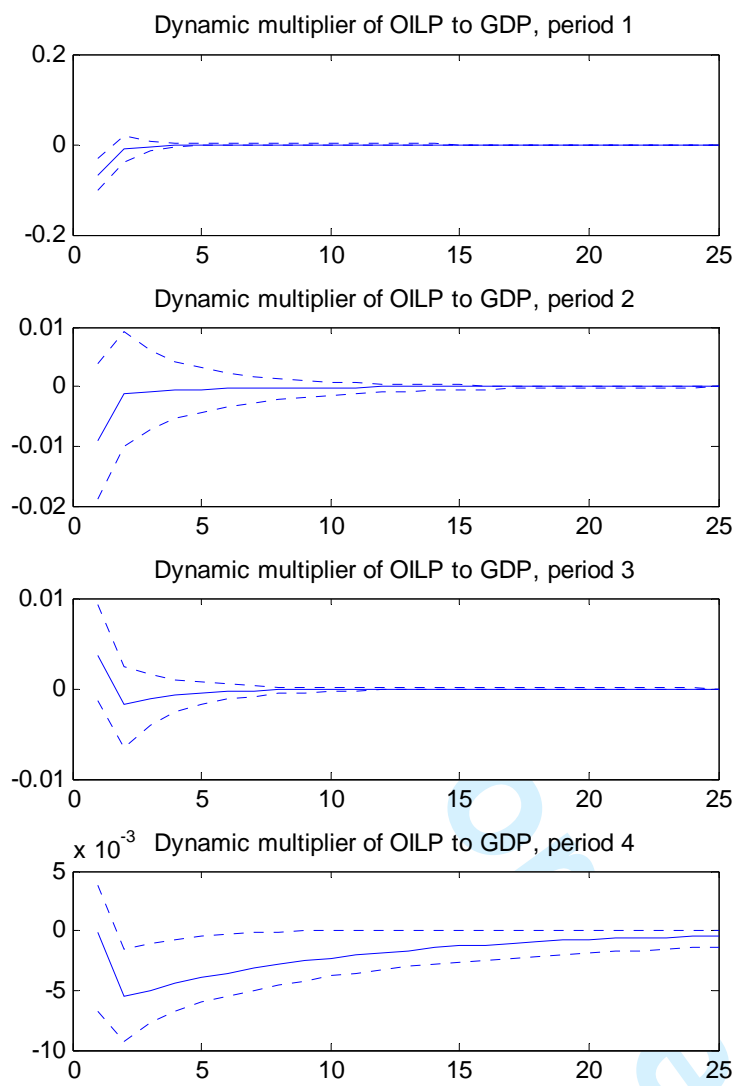

\section{ITALY}
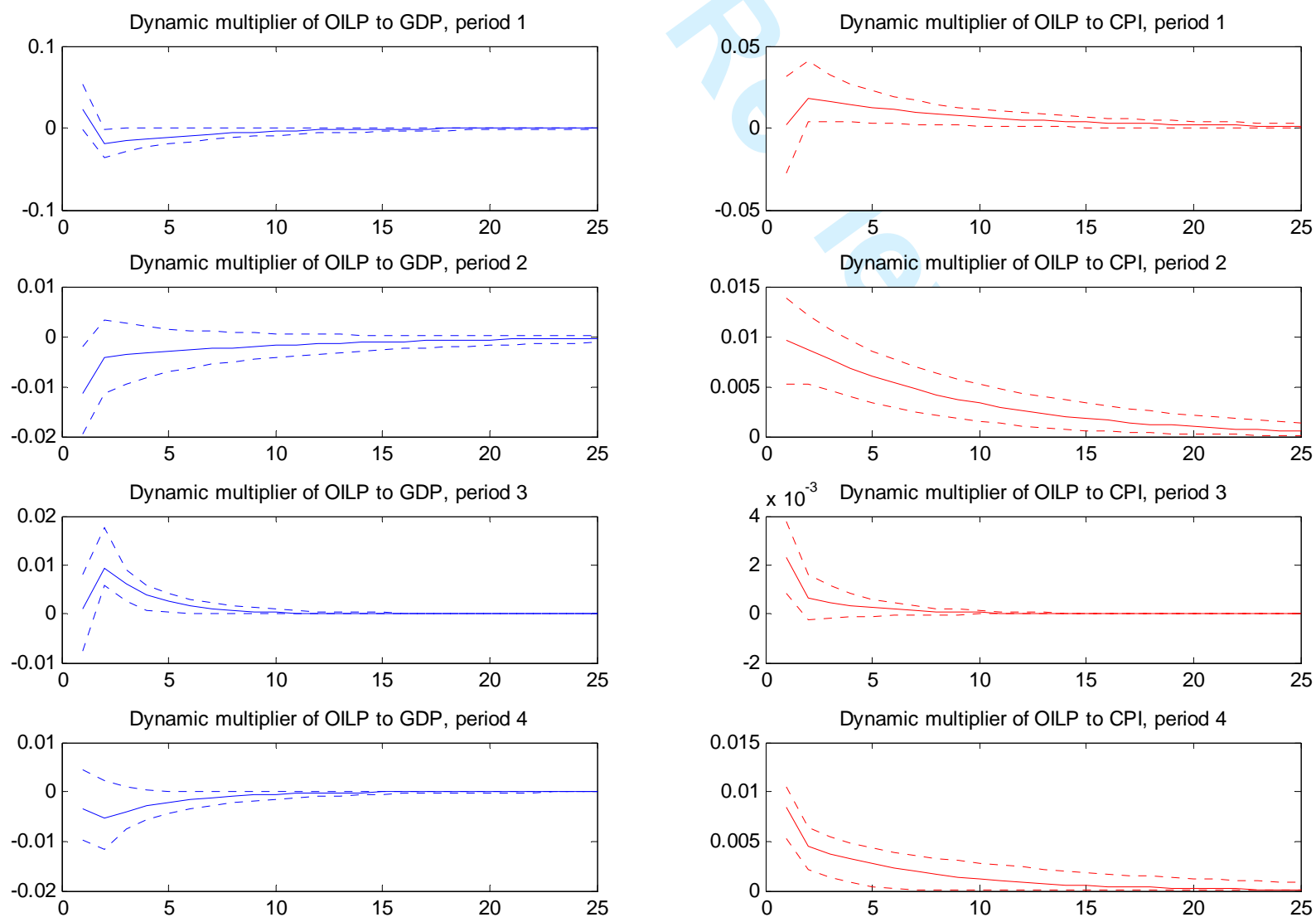